\title{
Malbsorption Today
}

\author{
Rui Ribeiro* \\ Coordinator of the Centro Multidisciplinar da Doença Metabólica da Clínica de Santo António, Portugal
}

Received: April 23, 2018; Published: May 11, 2018

*Corresponding author: Rui Ribeiro, Coordinator of the Centro Multidisciplinar da Doença Metabólica da Clínica de Santo António, AmadoraLisboa, Portugal; Tel: 351962669795; Email: ruijsribeiro@gmail.com

\section{Opinion}

In the modern metabolic surgery field the so called "malabsorption techniques" are more and more used as they allow better outcomes about weight loss and comorbidities control. By definition, malabsorption is a pathologic state result of anatomic or physiologic modifications across the gastrointestinal tract leading to a reduced absorption of food nutrients [1]. In our opinion malabsorption is a name in a bad use for the purposes of weight loss surgery. Malabsorption is a disease and doctors don't want to create the disease but only to take advantage of a secondary effect of it. If the advantage comes from the disease itself or from some happy parallel effect it's now a matter of discussion and research.

Some authors defend the use of different terms like hypoabsorption [2], limited absorption [3], dis-absorption or low level absorption [4]. They try to make a difference between malabsorption the disease and malabsorption the benefic effect from a controlled reduction of some nutrients absorption. In this article we'll keep using the designation of "malabsorption surgery" as it is the most known, generic and widespread in the literature.

As we know biliopancreatic diversion with duodenal switch (BPD-DS) is consensually the operation with the maximal effectiveness, we surprisingly notice only less than $2 \%$ of the surgeons all over the world are offering this technique to their patients [5]. The reasons for such a paradox are probably the technical operative difficulties, the higher early complications rate but, and this may be the main one, the nutritional deficits and secondary diseases patients do face when submitted to this technique. In this option surgeons accept the risk of a somehow higher post-operative morbidity rate and for life nutritional deficits in the future.

Malabsorption seems to be a phantom who scares doctors and patients keeping them far away of it. Some, rightly so, use to say "it's dangerous to combine restriction and malabsorption". Those are the ones who do pretend to avoid those undesirable kinds of nutritional difficulties, going to the alternative which is usually a restrictive, or predominantly restrictive, type of operation. But those, unfortunately, fails too often in the following years. Revisions or conversions as second surgical acts are then needed and those are more risky, expensive and misery inducers to the patients.

In an appraisal of both strategies nobody is sure of the more convenient risk/benefit profile. May be this is why, nowadays, a lot of metabolic surgeons are trying to reshape the malabsorption style of operations. They do use malabsorption in a smaller "dosis" and combine it with restriction. This is the mood of operations like "One Anastomosis Gastric Bypass" (OAGB), "Single Anastomosis Duodeno-Ileal with Sleeve gastrectomy" (SADI-S), "Single Anastomosis Sleeve-Ileal bypass" (SASI) or "Sleeve Gastrectomy with Ileal Interposition" (SGIT). The outcomes, better weight loss and increased operative safety of these approaches, are promising but need to be reproduced and confirmed in the future.

In the horizon of those bold doctor brains shines the desire to control well this very serious disease, inducing a fair weight loss, comorbidities control and quality of life improvement. In the top of the stage, there will be always the most possible benefit to the patient life. And probably some improvement in figures like the $42 \%$ reduction of the cardiovascular risk and $30 \%$ reduction of all-cause mortality [6] offered now to the surgically treated metabolic patients. Because of this spreading all doctors in the medical society needs to get additional education and knowledge about some rules counseled in patients submitted to malabsorptive operations.

In the pre-operative work up, there are different rules when someone considers to offer a patient an operation with a malabsorption component. First, not every patient is prone to this option. In addition to the regular contra-indications for bariatric surgery, people who don't understand the concept, people who is not able to attend the follow up appointments, to accomplish the examinations schedule, are not good candidates to malabsorption surgery. Again, social issues like profession or marital conditions may not be compatible with a new status 
where an increased bowel activity and meteorism are not so scarce. Financial capacity to achieve and eat good protein and to buy the recommended supplements is essential in terms of good adaptation in the future.

In the post-operative period, nutritional consequences may arise in patients even if they take properly the advised vitamins and mineral supplements along the follow up time. Some are common like anemia $[7,8]$ or vitamin D and osteoporosis [9], other are very rare but too serious to be allowed like hypoproteinemia [10], irreversible neuropathies [11] or xeroderma, xerostomy or even ophthalmoplegia $[12,13]$. The key to close the door to this kind of secondary diseases is strongly linked to the patient education and outreach to be compliant with the dietary protocols, to the supplementation rules and, the last but not the least, to the scheduled appointments the appropriate members of the bariatric team.

It is important to say all those nutritional deficits are preventable and, somehow, easily treatable by well-informed teams, if the patient shows up routinely. Drop out is, unfortunately, a sad reality limiting the power of the proposed therapy [14]. About half of participants in surgical weight-loss programs drop out before completing them [15]. Doctors and patients need to commit, together, for a long and regular interaction in order to ensure the success of the therapeutic plan.

Yet, the malabsorption mechanisms of action are not completely understood. Because of its complexity and multiple etiologies this class of diseases depends not only on the absorptive phenomena but also on other diseases (ex: inflammatory bowel diseases) or medicines (ex: diuretics) patients may present. In the bariatric and metabolic field, the "million dollars question" is now "how to combine malabsorption with restriction in a safe and effective pattern, in the sense of avoiding or limiting risks to the minimal incidence with a raise in weight loss and metabolic results.

The outcomes of the classic bariatric techniques are well established in the current literature $[5,6]$ showing enough safety and effectiveness to justify the generalized acceptance and practice all over the world. The new methods with some degree of malabsorption may burst into a new paradigm soon. There is now some discussion and different interpretations about the optimized of malabsorption in the weight loss and comorbidities improvement. If it is the weight loss augmented effect because of fat and protein malabsorption or due to other mechanisms which stimulate metabolic and neuroendocrine pathways is under investigation. Bile acid metabolism, microbiome changes and enterocyte glucose transport systems are the main suspects who deserve to arrest our attention in the near future of metabolic surgery.

\section{References}

1. Jensen JE (2007) Malabsorption Syndromes-Page 1. Colorado center for digestive disorders.

2. Gagner M (2016) Hypo absorption not malabsorption, Hypo absorptive surgery and not malabsorptive surgery. Obes surg 26(11): 2783-2784.

3. Zhi J, Melia AT, Eggers H, Joly R, Patel IH (1995) Review of limited systemic Absorption of orlistat, a Lipase Inhibitor, in healthy human volunteers. J Clin Pharmacol 3(11): 1103-1108.

4. Cavalieri L, Franzói de Morales SM (2004) Técnicas cirúrgicas no combate a obesidade mórbida. Arq Ciênc Saúde Unipar Umuarama 8(1): 49-54

5. Angrisani L, Santonicola A, Iovino P, Formisano G, Buchwald H, et al. (2015) Bariatric Surgery Worldwide 2013. Obes Surg 25(10): 18221832.

6. Lupoli R, Lembo E, Saldalamacchia G, Avola CK, Angrisani L, et al. (2017) Bariatric surgery and long-term nutritional issues. World J Diabetes 8(11): 464-474.

7. Shikora SA, Kim JJ, Tarnoff ME (2007) Nutrition and Gastrointestinal Complications of Bariatric Surgery. Nutr Clin Pract 22(1): 29-40.

8. Ribeiro R, Guerra A (2017) Intractable Iron Deficiency after Gastric Bypass Surgery. JOJ Case Stud 3(2).

9. Yu EW (2018) Bariatric Surgery: Weighing In on Bone Loss. J Bone Miner Res doi: 10.1002/jbmr.3432.

10. Suárez Llanos JP, Fuentes Ferrer M, Alvarez Sala Walther L, García Bray B, Medina González L (2015) Protein malnutrition incidence comparison after gastric bypass versus biliopancreatic diversion. Nutr Hosp 32(1): 80-86.

11. Joseph R Berger (2004) The Neurological Complications of Bariatric Surgery. Arch Neurol 61(8): 1185-1189.

12. Guerreiro AR, Ribeiro R (2015) Ophthalmic Complications of Bariatric Surgery. Obes Surg 25(1): 167-173.

13. Ramos Leví AM, Pérez Ferre N, Sánchez Pernaute A, Torres García AJ, Rubio Herrera MA (2013) Severe vitamin A deficiency after malabsortive bariatric surgery. Nutr Hosp 28(4): 1337-1340.

14. Gill RS, Karmali S, Hadi G, Al Adra DP, Shi X, et al. (2012) Predictors of attrition in a multidisciplinary adult weight management clinic. Can J Surg 55(4): 239-243.

15. Adam Diamant (2014) More than half of obese patients opt out of the bariatric surgical procedure process despite being in a publicly funded health care program. JACS 219(5): 1047-1055. 


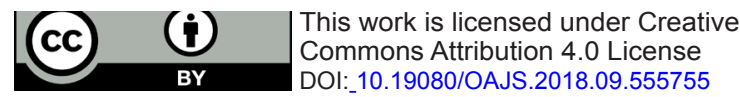

\section{Your next submission with Juniper Publishers} will reach you the below assets

- Quality Editorial service

- Swift Peer Review

- Reprints availability

- E-prints Service

- Manuscript Podcast for convenient understanding

- Global attainment for your research

- Manuscript accessibility in different formats ( Pdf, E-pub, Full Text, Audio)

- Unceasing customer service

Track the below URL for one-step submission https://juniperpublishers.com/online-submission.php 